\title{
Maassamuuttajien ominaisuuksista
}

\author{
MARKETTA RITAMIES
}

Väestöpoliittinen Tutkimuslaitos

Muuttoliiketutkimuksen piirissä on muuttajien ominaisuuksien tutkiminen saanut osakseen suhteellisen vähän huomiota. Eräänä syynä tähän lienee se, että ominaisuuksia on vaikea tutkia. Niiden kartoittaminen ennen muuttoa on melko mahdotonta, koska emme tiedä kuka on muuttaja. Muuton tapahduttua, jolloin tutkiminen on helpompaa, on kuitenkin muutto jo saattanut vaikuttaa heidän sosio-ekonomiseen asemaansa, tapoihinsa, perhe-elämäänsä ja terveyteensä.

Muuttajien ominaisuudet todennäköisesti heijastavat tapahtuvia sosiaalisia ja taloudellisia muutoksia. Koska muutokset vaihtelevat ajasta ja paikasta riippuen, on ilmeistä, että muuttajien ominaisuudetkaan eivät voi pysyä kiinteinä. Ei ole tarpeellista, ehkä ei mahdollistakaan, esittää yleistyksiä muuttajien ominaisuuksista. Sen sijaan on tärkeätä ja hyödyllistä tutkia ominaisuuksia eri ajankohtina ja erilaisissa olosuhteissa. Niiden tunteminen auttaa paremmin ymmärtämään väestön koostumuksessa havaittavia eroavuuksia ja niitä muutoksia, joita esiintyy muuttajan lähtö- ja tulopaikkakunnalla.

Muuttajien ominaisuudet voidaan jakaa kahteen ryhmään, helposti ja vaikeasti tutkittaviin. Ensimmäiseen ryhmään kuuluvat väestötilastoista saatavat sukupuoli, ikä, siviilisääty, usein vielä koulutus ja ammattikin. Vaikeammin tutkittavia ovat sen sijaan sellaiset tärkeät ominaisuudet kuin fyysinen ja henkinen terveys, älykkyys ja persoonallisuus. Useimmat tutkimukset ovatkin syrjäyttäneet vaikeasti tutkittavat ominaisuudet keskittyen vain väestölaskennoista saataviin tietoihin.

Väestötilastomme - vaikka antaakin suhteellisen hyvän yleiskuvan muuttoliikkeestä - kiinnittää huomiota vain muutamiin muuttajien ominaisuuksiin. Tämän selvityksen tarkoituksena on tutkia niitä 1960-luvun alkupuolen maassamuuttajien ominaisuuksia, joihin virallisen muuttoliiketilastomme perusteella on mahdollisuus. Sen puitteissa selvitetään minkälaisista ihmisistä muodostuu tämä yli 200000 hengen suuruinen maassamme vuosittain muuttava ihmisryhmä ja eroaako se näiden ominaisuuksien perusteella koko väestöstä. Lyhyt katsaus ulko- ja kotimaisten tutkimusten tuloksiin osoittaa mitä muuttajien ominaisuuksia on tutkittu aikaisemmin ja missä määrin muuttoliikkeen on todettu olevan niiden suhteen valikoivaa. 


\section{Maassamuuton valikoivuus suoritettujen tutkimusten valossa}

Ulkomaiset tutkimukset

Muuttajien ominaisuuksia käsittelevät tutkimukset ovat usein olleet teoreettisia, lähinnä universaalisia yleistyksiä tavoittelevia. Muuttajien on oletettu muodostavan yksinkertaisen kategorian, josta voi esittää yleistyksiä. Lukuisista tutkimuksista huolimatta ei ole kuitenkaan pystytty esittämään kuin joitakin ylimalkaisia yleistyksiä ja tutkijat ovat päätyneetkin siihen, että yleistysten löytäminen ei ole tarpeellista, ei edes suotavaakaan.

Väestötilastoista helposti saatavia ominaisuuksia käsitteleviä tutkimuksia on lukuisia. Niiden perusteella voidaan muuttoliikkeen valikoivuudesta todeta seuraavaa:

1. Muutto valikoi nuoria ihmisiä. Tutkijat ovat siitä yksimielisiä, ja siksi tämä onkin eräs lujimmista demografian piirissä esitetyistä yleistyksistä. Bogue $(1959,504)$ esittää muuton olevan valikoivaa lähinnä teini-iästä 35 vuoden ikään saakka, vaikka toisaalta on todettavissa sellaisiakin muuttovirtoja, joissa lapset ja vanhukset ovat tavallista runsaammin edustettuina. Eräänä syynä siihen, että muuttoliike valikoi nuoria ihmisiä, pidetään sitä, että nuoret pystyvät sopeutumaan paremmin asuinpaikan mukanaan tuomiin muutoksiin kuin vanhemmat henkilöt. (Petersen 1961, 593).

2. Maassamuutto on sukupuolen suhteen valikoivaa. Kuitenkin erilaisista olosuhteista riippuu kumpi sukupuoli vallitsee kussakin muuttovirrassa. Lee $(1966,3,48)$ mainitsee jo Ravensteinin havainneen tämän, sillä esittäessään naisten muuttavan enemmän kuin miesten, Ravenstein totesi tämän pitävän paikkansa erityisesti silloin kun oli kysymys lähimuutoista. Yhdysvalloissa miesten on todettu olevan taipuvaisempia muuttamaan. Erityisesti kaukomuutot ovat heille ominaisia. Myös silloin kun tulopaikkakunnan olosuhteet ovat epävarmat tai vaikeat ovat miehet muuttajien enemmistönä (Bogue 1959, 504).

3. Maassamuutossa havaitaan tapahtuvan siviilisäädyn mukaista valintaa. Samalla on kuitenkin otettava huomioon myös muita ominaisuuksia. Esim. ikä liittyy läheisesti siviilisäätyyn. Ruotsissa naimattomien on todettu muuttavan enemmän kuin samanikäisten naimisissa olevien. (Wallander 1948, 166). Muuton on katsottu usein valikoivan yhteiskunnan mahdollisimman vähän sitomia ihmisiä. Tällaisia ovat lähinnä naimattomat, lesket ja eronneet (Illsley, Finlayson, Thomas 1963, 3, 237-238).

4. Maassamuuton ammatinmukainen valinta on suuresti riippuvainen yhteiskuntatyypistä ja ajankohdasta. Esimerkiksi sodan vaikutus voi olla huomattava muuttoliikkeen ammatinmukaiseen valintaan vaikuttava tekijä. 
Ammatinmukainen valinta vaatii siis valintaa muissakin suhteissa, koska se liittyy sosiaaliseen taustaan ja käyttäytymiseen.

Muuttoliiketutkimuksissa on useimmiten syrjäytetty sellaisten ominaisuuksien tutkiminen, joista ei ole saatavissa valmista materiaalia tai joista saatava materiaali on epävalidia tai puutteellista. Vaikka psyykkiset tekijät kuten älykkyys ja mentaalinen terveys ovat vaikeasti tutkittavissa, on niihin silti useissa tutkimuksissa kiinnitetty huomiota. Tosin niissä käytetyt metodologiat ovat useimmiten olleet riittämättömiä. Vanhemmat tukimukset ovat pyrkineet osoittamaan, että urbanisaatio valikoi maalaisväestön älykkäämpää ainesta. Päätelmä on kuitenkin viime aikoina pystytty useissa tutkimuksissa osoittamaan vääräksi. Joidenkin tutkijoiden mielestä psyykkisistä tekijöistä ei voida tehdä yleistyksiä. Muutto valikoi joissakin tilanteissa älykkäitä, toisissa taas vähemmän älykkäitä ja joskus ei valintaa tapahdu ollenkaan (Petersen 1961, 602).

Muuttajien fyysistä terve y t ä käsittelevät tutkimukset ovat usein olleet valideja vain tietyissä olosuhteissa. Ne ovat käsitelleet jotakin erityistä probleemaa tiettynä ajankohtana. Tukholmassa esim. on tutkittu tuberkuloosiin kuolleita, ja todettu kaupunkiin muuttaneiden kuolevan harvemmin tuberkuloosiin kuin syntyperäisten kaupunkilaisten (Illsley, Finlayson, Thomas 1963, 3, 299). Muuttoliike yleensä valikoi väestön terveintä ainesta, koska nuoriso muodostaa siitä suuren osan. Tosin saattaa esiintyä sellaisiakin muuttovirtoja, joissa huono terveys on syynä muuttoon.

Kotimaiset tutkimukset

Suomessa on maassamuuttajien ominaisuuksia tutkittu vähän. Meillä ei ole suoritettu tutkimuksia, joissa olisi keskitytty yksinomaan muuttajien ominaisuuksien tarkasteluun. Tutkijat ovat olleet kiinnostuneempia muuttoliikkeen laajuudesta, vilkkaudesta ja suunnasta kuin siitä, minkälaisista ihmisistä se koostuu.

Muuttoliiketilastomme perustuu suurimmaksi osaksi Tilastollisen päätoimiston keräämään otanta-aineistoon. Otanta-aineisto sisältää jokaisen kuntaan muuttaneen henkilön, joka on syntynyt kuukauden 5,15 ja 25 päivänä ja käsittää siten noin $10 \%$ kaikista muuttaneista. Tämän aineiston perusteella saadaan maassamuuttajista seuraavat tiedot: lähtö- ja saapumispaikkakunta ja vastaavat rekisterit, muuttaneen henkilön nimi, syntymäaika, syntymäkunta, sukupuoli, siviilisääty, oma ja päämiehen ammatti sekä perheasema. Myös yhdessä muuttaneen perheen kokoonpano on ilmoitettu. Tämä edustava aineisto selvittää lähinnä muuttaneiden prosenttista jakaantumista erilaisten ominaisuuksien mukaan (Fougstedt 1953, 3, 356$357)$. 
Maassamuuttajien on todettu olevan meillä samoin kuin muualla maailmassa iän, sukupuolen, siviilisäädyn ja ammatin mukaan jossain määrin valikoivaa.

1. Iältään muuttajat kuuluvat nuorisoon. Lento (1951, 72) havaitsi naisten muuttavan Helsinkiin eniten 20-24-vuotiaina ja miesten 25-29vuotiaina. Uudenmaan läänin muuttajista esi-industrialistisen kauden lopulla yli puolet oli 19-29 vuotiaita. (Rosenberg, 1966, 71).

2. Naisten muuttolukujen on meillä todettu olevan korkeammat kuin miesten. Varsinkin maalta kaupunkeihin ja kauppaloihin suuntautuvan muuttoliikkeen on havaittu valikoivan naisia. (Lento, 1948, 108-111). Naisten enemmyyden on meillä oletettu johtuvan siitä, että heidän osuutensa työvoimasta ja korkeakouluopiskelijoista on kansainvälisesti katsoen korkea (Valkonen-Kukkonen, 1966, 29).

3. Naimattomien osuus muuttaneista on huomattava. Sjöberg (1947, 32-34) totesi tämän Perttelin muuttoliikettä tutkiessaan, vaikka siellä oli erinäisistä syistä muuttanut tavallista enemmän naimisissakin olevia.

4. Maassamuuton ammatinmukaisen valikoivuuden tutkimista meillä vaikeuttaa ammattitilaston epäluotettavuus. Se perustuu kirkonkirjoihin, joiden ammattinimitykset ovat usein vanhentuneita. Tutkimukset tavallisimmin käsittelevät maalta kaupunkiin muuttaneita. Lento (1948, 122123) havaitsi, että Kuopion läänin asutuskeskuksiin muuttavat olivat maatalousväestöstä peräisin. Rosenbergin (1966, 54) mukaan muuttajat olivat Uudellamaalla vv. 1820-70 lähinnä maatilatalouden piirissä työskentelevää palvelusväestöä. 1950-luvulla Helsinkiin muuttajista suurimman ryhmän muodostivat käsityöläiset ja muut työntekijät. Seuraavina olivat ilman ammattia olevat ja maa- ja metsätaloustyöntekijät. Ilman ammattia olevien suuri osuus johtuu siitä, että suuri osa nuorista muuttajista muuttaa juuri ensimmäiseen työpaikkaansa. (Bruun 1955, 3, 68).

Maassamuuttajien älykkyyttä käsitteleviä tutkimuksia on vähän. Allardt, Jartti, Jyrkilä ja Littunen (1958, 180-181) tutkivat tiedollisen aktiivisuuden asteikon avulla maaltamuuttajien tiedollista vireyttä. Maaseudulta kaupunkiin muuttavien todettiin olevan tiedollisesti vireämpiä kuin kaupungeista maaseudulle tai maalaiskunnista maalaiskuntiin muuttavien. Valkonen ja Kukkonen (1966, 24-40) tutkivat eroaako Ristiinasta muuttava nuoriso lahjakkuudeltaan paikallaanpysyvästä. Lahjakkuuden mittarina he käyttivät koulumenestystä ja koulunkäynnin määrää. Koulussa hyvin menestyneiden todettiin muuttavan keskimääräistä useammin pois Ristiinasta. Myös koulunkäynnin määrän ja muuttoalttiuden välillä havaittiin voimakas riippuvuus, miesten kohdalla se oli vielä selvempi kuin naisten kohdalla.

Nuorten suuresta osuudesta muuttoliikkeessä johtuu, että muutto valikoi väestön terveintä ainesta. Meillä ei ole varsinaisia muuttaneiden terveydentilaa käsitteleviä tutkimuksia, sen sijaan heidän kuolevuuteensa on viitattu joissakin tutkimuksissa. Piepponen ja Ritamies $(1966,21-22)$ tote- 
sivat Helsinkiin muuttaneiden kuolevuuden olevan pienemmän kuin lähtöpaikkakunnalla olevien, lukuunottamatta maaseudulta muuttaneita miehiä. Näiden kuolevuus oli Helsingissä suurempi kuin lähtöpaikkakunnalla. Miehet ovat todennäköisesti tottumattomia torjumaan vaaroja, joita uudenlaiset tehtävät ja vaaranalainen työ tarjoavat.

Aivan päinvastaiseen tulokseen tuli Varpela $(1964,5,27)$ tutkiessaan kokonaiskuolleisuutta kaupunkiin suuntautuvan muuttoliikkeen yhteydessä. Hän havaitsi muuttajien kuolleisuuden olevan paljon suuremman kuin syntyperäisten kaupunkilaisten ja lähtöpaikkakunnan asukkaiden. Tämä johtui lähinnä yli 30 -vuotiaiden miesten suuresta kuolleisuudesta. Varpelan saamaan tulokseen ilmeisesti vaikutti osaksi se, että muuttaneet olivat saattaneet asua jo useita vuosia kaupungissa, joten heidän kuolleisuuslukunsa kuvasti paremminkin pysyvän uuden ympäristön vaikutuksia.

\section{Maassamuuttajien ominaisuudet}

Maassamuuttajien määrä on jatkuvasti kohonnut. Kun heitä muutti vuosina 1951 -55 keskimäärin 160000 henkeä vuosittain, on vastaava määrä vuosina 1960 -65 jo 217000 eli $4.9 \%$ keskiväkiluvusta. Muutot eivät enää 1960-luvulla suuntaudu niin paljon kuin 1950-luvun alkupuolella maalaiskunnista maalaiskuntiin. Niiden osuus on vähentynyt $41.3 \%$ :sta 29.5 $\%:$ iin. Sen sijaan kaupunkien ja kauppaloiden välisten muuttojen osuus on lisääntynyt $13.3 \%$ :sta $19.8 \%$ :iin.

Seuraavassa on tarkoituksena tutkia 1960-luvun alkupuolella muuttaneen väestöryhmän ominaisuuksia väestötilastojen perusteella. Muuttajien ominaisuuksia pyritään tutkimaan, mikäli mahdollista, vuosina 1960 65. Useimpien ominaisuuksien kohdalla kahden ensimmäisen vuoden tilastot kuitenkin perustuvat kokonaisaineistoon eivätkä siten ole vertailukelpoisia muiden, otantaan perustuvien, tietojen kanssa. Useimmiten joudutaan keskittymään vuosina 1962-65 muuttaneiden ominaisuuksiin. Tilastojen suomien mahdollisuuksien puitteissa pyritään ottamaan huomioon muuttajien ominaisuuksiin mahdollisesti vaikuttavat tekijät, kuten muuton suunta ja pituus sekä alueelliset eroavuudet.

\section{Sukupuoli}

Suomessa on naisten muuttoliike ollut aina vilkkaampaa kuin miesten. Jo 1800-luvun alkupuolella he muuttivat enemmän kuin miehet. Myöskään vuodet 1960 - 65 eivät tee poikkeusta, vaan naisten osuus muuttaneista on $53.2 \%$. Vaikka otettaisiin huomioon, että naisten osuus kokonaisväestöstäkin on suurempi $(51.8 \%)$ kuin miesten, osoittavat taulukon 1 promilleluvut kuitenkin, että heidän suhteellinen osuutensa on muuttajien keskuudessa jonkin verran suurempi kuin miesten. 
T a ulukko 1. Maassamuutto vuosina 1960-65 keskiväkiluvun 1000 henkeä kohden

Table 1. Average internal migration between 1960-1965 per 1000 persons

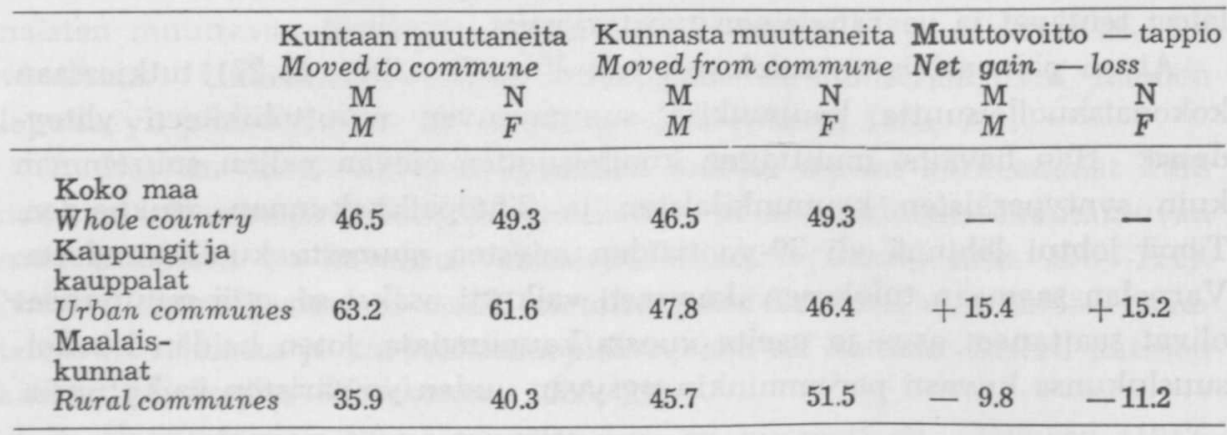

Ta ulukko 2. Maassamuutto muuton suunnan mukaan vuosina 196265 prosentteina

Table 2. Internal migration between 1962-1965, according to direction of migration (in per cent)

\begin{tabular}{|c|c|c|c|c|c|c|}
\hline & \multirow[b]{2}{*}{$\begin{array}{l}\text { Kaupun- } \\
\text { geista ja } \\
\text { kauppa- } \\
\text { loista } \\
\text { From } \\
\text { urban } \\
\text { communes }\end{array}$} & \multicolumn{2}{|l|}{$\begin{array}{l}\text { Miehet } \\
\text { Men }\end{array}$} & \multirow{2}{*}{$\begin{array}{l}\text { Kaupun- } \\
\text { geista ja } \\
\text { kauppa- } \\
\text { loista } \\
\text { From } \\
\text { urban } \\
\text { communes }\end{array}$} & \multicolumn{2}{|l|}{$\begin{array}{l}\text { Naiset } \\
\text { Women }\end{array}$} \\
\hline & & $\begin{array}{l}\text { Maalais- } \\
\text { kunnista } \\
\text { From } \\
\text { rural } \\
\text { communes }\end{array}$ & Yhteensä & & $\begin{array}{l}\text { Maalais- } \\
\text { kunnista } \\
\text { From } \\
\text { rural } \\
\text { communes }\end{array}$ & Yhteensä \\
\hline $\begin{array}{l}\text { Kaupunkeihin } \\
\text { ja kauppaloihin } \\
\text { To urban } \\
\text { communes } \\
\text { Maalaiskuntiin }\end{array}$ & 22.0 & 32.3 & 54.3 & 22.4 & 32.1 & 54.5 \\
\hline $\begin{array}{l}\text { To rural } \\
\text { communes }\end{array}$ & 19.7 & 26.0 & 45.7 & 19.2 & 26.3 & 45.5 \\
\hline $\begin{array}{l}\text { Yhteensä - Total } \\
\text { N }\end{array}$ & 41.7 & 58.3 & $\begin{array}{r}100.0 \\
78713\end{array}$ & 41.6 & 58.4 & $\begin{array}{r}100.0 \\
90377\end{array}$ \\
\hline
\end{tabular}

Kaupungit ja kauppalat ovat saaneet muuttovoittoa maalaiskuntien kärsiessä tappiota. Kummankin sukupuolen keskuudessa on kaupunkien ja kauppaloiden suhteellinen muuttovoitto melkein yhtä suuri. Sen sijaan naiset ovat maalaiskunnissa kärsineet suhteellisesti hieman enemmän muuttotappiota.

On syytä tarkastella mikä vaikutus muuton sukupuolivalikointiin on muuton suunnalla ja pituudella sekä tutkia eroavatko maan eri osat tässä suhteessa toisistaan. 
Naisten osuus maassamuuttajista ei vaihtele muuton suunnan mukaan. Heitä on 53-54\% suuntautuivatpa muutot maalaiskuntiin tai kaupunkeihin tai niistä poispäin. Taulukossa 2 on esitetty erikseen naisten ja miesten muuttojen jakaantuminen muuton suunnan mukaan vuosina 1962 65.

Muuton suunta ei vaikuta muuton sukupuolivalikointiin. Maalaiskunnista kaupunkeihin ja kauppaloihin suuntautuvat muutot ovat kummankin sukupuolen keskuudessa yleisimmät. Vähiten muutetaan päinvastaiseen suuntaan.

Jo 1890-luvun loppupuolella Ravenstein havaitsi lähimuuttojen olevan naisille ominaisempia kuin miehille. Useat muut tutkijat ovat tulleet samaan tulokseen toteamalla, että naisten osuus muuttaneiden kokonaismäärästä pienenee muuttomatkan pidentyessä. Helsingin muuttotilasto ei kuitenkaan Lennon tutkimuksessa antanut tukea tälle käsitykselle (Lento 1951, 76). Myös hänen Kuopion läänin kunnissa suorittamansa tutkimus osoitti naisten muuton lähikuntiin olevan vähäisempää kuin miesten (Lento 1948, 111).

Kun tässä selvityksessä tutkitaan muuton pituuden vaikutusta sukupuolivalikointiin 1960-luvun alkupuolella, pidetään läänin sisäisiä muuttoja lähimuuttoina ja läänien välisiä kaukomuuttoina. Väestötilastojen perusteella on mahdollista tarkastella vain vuosia 1960 -62, koska vuodesta 1963 lähtien ei ole saatavissa tietoja kummastakaan sukupuolesta erikseen.

Vuosina 1960 - 62 oli lähimuuttojen osuus $55 \%$ kaikista muutoista. Naisten osuus lähimuutoista oli $53 \%$. Tämä ei kuitenkaan osoita sitä, että lähimuutot olisivat naisille tyypillisiä, koska naisten osuus oli $53 \%$ kaukomuutoistakin. He muuttavat enemmän kuin miehet muuton pituudesta riippumatta.

Maan eri osat eroavat melkoisesti lähi- ja kaukomuuttojen suhteen. Lähimuutot ovat tyypillisimpiä Turun ja Porin läänille (67 \%). Myös Vaasan, Oulun ja Pohjois-Karjalan lääneissä oli lähimuuttojen määrä yli $60 \%$. Hämeen läänille sen sijaan ovat yleisimpiä kaukomuutot, sillä lähimuuttojen osuus oli siellä vain $47 \%$. Myös Uudenmaan ja Mikkelin läänissä oli lähimuuttojen määrä pienempi kuin kaukomuuttojen.

Sukupuolten väliset eroavuudet maan eri osissa ovat pienet. Naisten osuus läänien lähimuutoista vaihtelee $52-56 \%$ :iin ja kaukomuutoista 51 $54 \%$ :iin. Niissä lääneissä, joissa naisten osuus lähimuuttajista on suuri, on heitä paljon myös kaukomuuttajien joukossa. Esim. Kuopion läänissä on naisten osuus suuri sekä lähi- että kaukomuuttajista ja Kymen läänissä vähäinen.

Jos ei eroteta lähi- ja kaukomuuttoja, vaan tutkitaan sukupuolen vaikutusta maan eri osien muuttovoittoon tai -tappioon, on tilanne vuosina 1960-63 kuvion 1 kaltainen. 


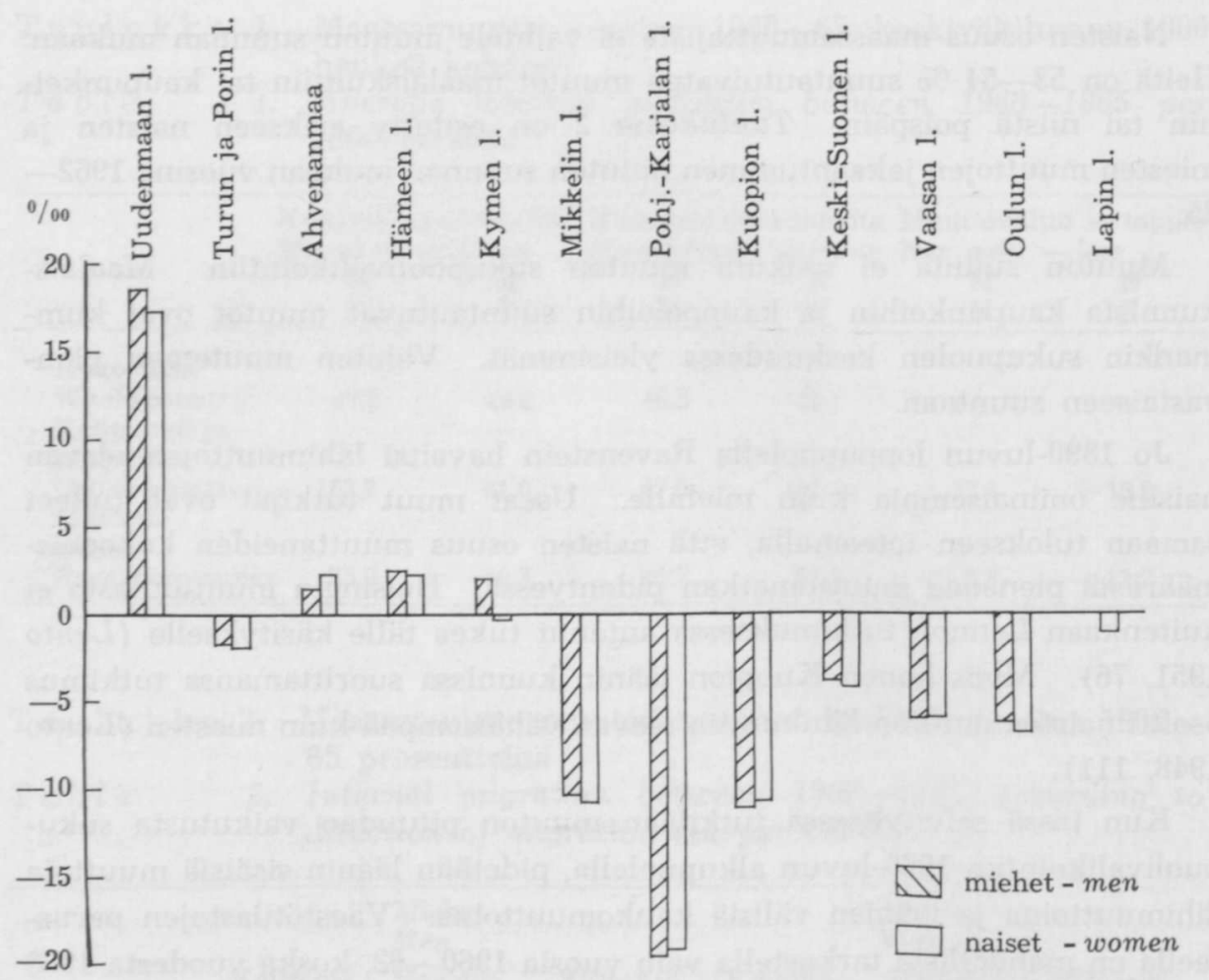

K u vio 1. Muuttovoitto ja -tappio keskiväkiluvun 1000 henkeä kohti lääneittäin vuosina $1960-63$

Figure 1. Average net gain and loss due to migration per 1000 persons between 1960-1963; according to administrative districts

Vaikka läänien välillä on huomattavia eroavuuksia niiden saaman suhteellisen muuttovoiton tai kärsimän muuttotappion suhteen, on sukupuolen vaikutus vähäinen. Uudellamaalla, joka on erikoisasemassa saamansa korkean muuttovoiton vuoksi, on miesten muuttovoitto hiukan suurempi kuin naisten. Suurin, noin $2 \%$ on sukupuolten välinen eroavuus Kymen läänissä, jossa miehillä todetaan muuttovoittoa, naisten muuttoliikkeen ollessa hieman tappion puolella. Muissa lääneissä sukupuolten välinen ero on useimmiten promillea vähäisempi.

I k ä

Maassamuuton iän mukaisesta valikoinnista tutkijat ovat yksimielisiä. Nuoriso muodostaa maassamuuttajien valtaosan ja naisten on todettu muuttavan jonkin verran nuorempina kuin miesten. Vuosina 1962-65 muuttaneiden ikäjakautuma osoittautui aikaisempien tutkimusten tuloksia tukevaksi. 
Ta u lukko 3. Maassamuuttajien ja koko väestön ikäjakautuma sukupuolen mukaan vuosina $1962-65 \%$ :na

Table 3. Age and sex distribution of migrants and the total population between 1962-1965 (in per cent)

\begin{tabular}{|c|c|c|c|c|c|c|}
\hline \multirow[t]{2}{*}{$\begin{array}{l}\text { Ikä } \\
\text { Age }\end{array}$} & \multicolumn{3}{|c|}{$\begin{array}{l}\text { Maassamuuttajat }{ }^{1} \text { ) } \\
\text { Migrants }\end{array}$} & \multicolumn{3}{|c|}{$\begin{array}{l}\left.\text { Koko väestö }{ }^{2}\right) \\
\text { Whole population }\end{array}$} \\
\hline & $\begin{array}{l}\text { Miehet } \\
\text { Men }\end{array}$ & $\begin{array}{l}\text { Naiset } \\
\text { Women }\end{array}$ & $\begin{array}{l}\text { Yhteensä } \\
\text { Total }\end{array}$ & $\begin{array}{l}\text { Miehet } \\
\text { Men }\end{array}$ & $\begin{array}{l}\text { Naiset } \\
\text { Women }\end{array}$ & $\begin{array}{l}\text { Yhteensä } \\
\text { Total }\end{array}$ \\
\hline $0-4$ & 13.6 & 11.5 & 12.5 & 9.2 & 8.2 & 8.7 \\
\hline $5-14$ & 15.5 & 13.3 & 14.3 & 20.1 & 18.0 & 19.0 \\
\hline $15-24$ & 25.3 & 33.6 & 29.7 & 18.7 & 16.8 & 17.7 \\
\hline $25-34$ & 25.7 & 21.3 & 23.4 & 13.7 & 12.4 & 13.0 \\
\hline $35-44$ & 10.1 & 8.7 & 9.4 & 12.7 & 12.7 & 12.7 \\
\hline $45-64$ & 8.1 & 8.9 & 8.5 & 19.6 & 22.4 & 21.1 \\
\hline $65-$ & 1.7 & 2.7 & 2.2 & 6.0 & 9.5 & 7.8 \\
\hline \multicolumn{7}{|c|}{ Yhteensä } \\
\hline Total & 100.0 & 100.0 & 100.0 & 100.0 & 100.0 & 100.0 \\
\hline$N$ & 78713 & 90378 & 169091 & 2209052 & 2368146 & 4577198 \\
\hline
\end{tabular}

1) perustuu otantaan based on a sample

$\left.{ }^{2}\right)$ perustuu vuotuiseen keskimäärään based on annual average

Maassamuuttajista $80.1 \%$ on alle 35 -vuotiaita, vastaavan osuuden ollessa koko väestöstä $58.4 \%$. 15-24-vuotiaat muodostavat suurimman ikäluokan (taulukko 3). Erityisesti naisten keskuudessa on tämän ikäisiä muuttajia paljon, noin kolmasosa kaikista naismuuttajista. Tähän ikäluokkaan kuuluvien miesten ja naisten välinen ero tulee vielä suuremmaksi kun otetaan huomioon, että koko väestössä tähän ikäluokkaan kuuluu miehiä enemmän, $51 \%$. Iän mukana muuttoalttius vähenee. Muuttajista vain $10.7 \%$ on 45 -vuotiaita tai sitä vanhempia. Koko väestöstä tähän ikäluokkaan kuitenkin kuuluu $28.9 \%$.

Syynä siihen, että naiset muuttavat nuorempina kuin miehet, pitää Lento $(1951,72-73)$ sitä, että tytöt kehittyvät nopeammin kuin pojat ja että tytöillä on jo varhaisella iällä tarjolla sopivaa työtä kotitaloudessa, kauppa- ja ravitsemisliikkeissä ym. Asevelvollisuusiän Lento katsoo vähentävän nuorten miesten muuttoja, vaikka se voi kyllä olla sysäyksenä myöhemmin tapahtuvalle asuinpaikan vaihdokselle.

Rosenberg $(1966,84)$ ei yhdy Lennon käsitykseen siinä, että tyttöjen nopeampi kehittyminen vaikuttaa naisten alhaisempaan muuttoikään. Hänen mielestään naisten ja miesten ikäryhmitysten suhde vaihteli muuttaneiden yhteiskunnallisesta asemasta riippuen.

Muuton suunnan vaikutus muuttajien ikärakenteeseen käy ilmi taulukosta 4. 
T a u l u k k o 4. Maassamuuttajien ikärakenne muuton suunnan mukaan vuosina $1962-65 \%$ :na

Table 4. The age structure of migrants between 1962-1965, according to direction of migration (in per cent)

\begin{tabular}{|c|c|c|c|c|}
\hline $\begin{array}{l}\text { Ikä } \\
\text { Age }\end{array}$ & $\begin{array}{l}\text { Kaupungeista } \\
\text { kaupunkeihin } \\
\text { From urban } \\
\text { communes } \\
\text { to urban } \\
\text { communes }\end{array}$ & $\begin{array}{l}\text { Kaupungeista } \\
\text { maalaiskuntiin } \\
\text { From urban } \\
\text { communes } \\
\text { to rural } \\
\text { communes } \\
\end{array}$ & $\begin{array}{l}\text { Maalaiskunnista } \\
\text { kaupunkeihin } \\
\text { From rural } \\
\text { communes } \\
\text { to urban } \\
\text { communes }\end{array}$ & $\begin{array}{l}\text { Maalaiskunnista } \\
\text { maalaiskuntiin } \\
\text { From rural } \\
\text { communes to } \\
\text { rural communes }\end{array}$ \\
\hline $0-4$ & 12.7 & 15.2 & 9.7 & 13.8 \\
\hline $5-14$ & 13.8 & 14.4 & 12.1 & 17.3 \\
\hline $15-24$ & 25.4 & 24.7 & 38.6 & 26.3 \\
\hline $25-34$ & 26.6 & 25.4 & 21.0 & 22.1 \\
\hline $35-44$ & 10.7 & 9.5 & 8.0 & 9.8 \\
\hline $45-64$ & 8.8 & 8.6 & 8.2 & 8.6 \\
\hline $65-$ & 2.0 & 2.2 & 2.4 & 2.1 \\
\hline \multicolumn{5}{|l|}{ Yhteensä } \\
\hline $\begin{array}{l}\text { Total } \\
\mathrm{N}\end{array}$ & 100.0 & 100.0 & 100.0 & 100.0 \\
\hline N & 37581 & 32817 & 54379 & 44314 \\
\hline
\end{tabular}

Merkittävin ero muuton suunnan ja ikäjakautuman välillä on se, että 15-24-vuotiaina maalaiskunnista muutetaan kaupunkeihin ja kauppaloihin huomattavasti enemmän kuin muihin suuntiin. Maalaiskunnista muuttaa kaupunkeihin alle 25-vuotiaina $60 \%$ muuttajista. Kaupungeista muuttajat taas ovat hieman useammin 25-34-vuotiaita.

Rosenberg katsoo muuttaneiden ikärakenteen ja muuton suunnan välisten eroavuuksien suurelta osalta johtuvan muuttaneiden ammattiryhmityksessä esiintyvistä muutoksista. Tosin hän olettaa maaseudun ja kaupungin välisten eroavuuksien aiheutuvan myös muuttoliikkeen maantieteellisestä luonteesta. Kaupunkien muuttoliike on enemmän kauttakulun luonteista. Sinne siirtyneistä suuri osa on jo aikaisemmin, nuorempana, muuttanut maalta kaupunkiin (Rosenberg 1966, 80-83).

Allardt, Jartti, Jyrkilä ja Littunen (1958, 179) totesivat 15-29-vuotiaiden tyttöjen muuttavan enemmän maaseudulta kaupunkiin ja samanikäisten poikien maaseudulta maaseudulle. Tässä selvityksessä tulokset eivät poikien osalta osoittaudu samanlaisiksi (taulukko 5).

Tytöt, 15-24-vuotiaat, muuttavat poikia useammin maalaiskunnista kaupunkeihin ja kauppaloihin, mutta maalaiskuntien väliset muutot eivät ole tämän ikäisille pojille yleisempiä, päinvastoin. Seuraavaksi vanhimmassa ikäluokassa heidän osuutensa sen sijaan on hiukan tyttöjen osuutta suurempi. Muuton suunnasta rippumatta tyttöjen osuus on suurempi 15-24-vuotiaiden ikäluokassa ja poikien 25-34-vuotiaiden ikäluokassa. Alle 15-vuotiaiden muuttajien osuus on poikien keskuudessa suurempi kaikkiin suuntiin tapahtuvissa muutoissa. 
T a ulukko 5. Maassamuuttajat iän, muuton suunnan ja sukupuolen mukaan vuosina $1962-65 \%$ :na

Table 5. The distribution of migrants between 1962-1965, according to age, sex, and direction of migration (in per cent)

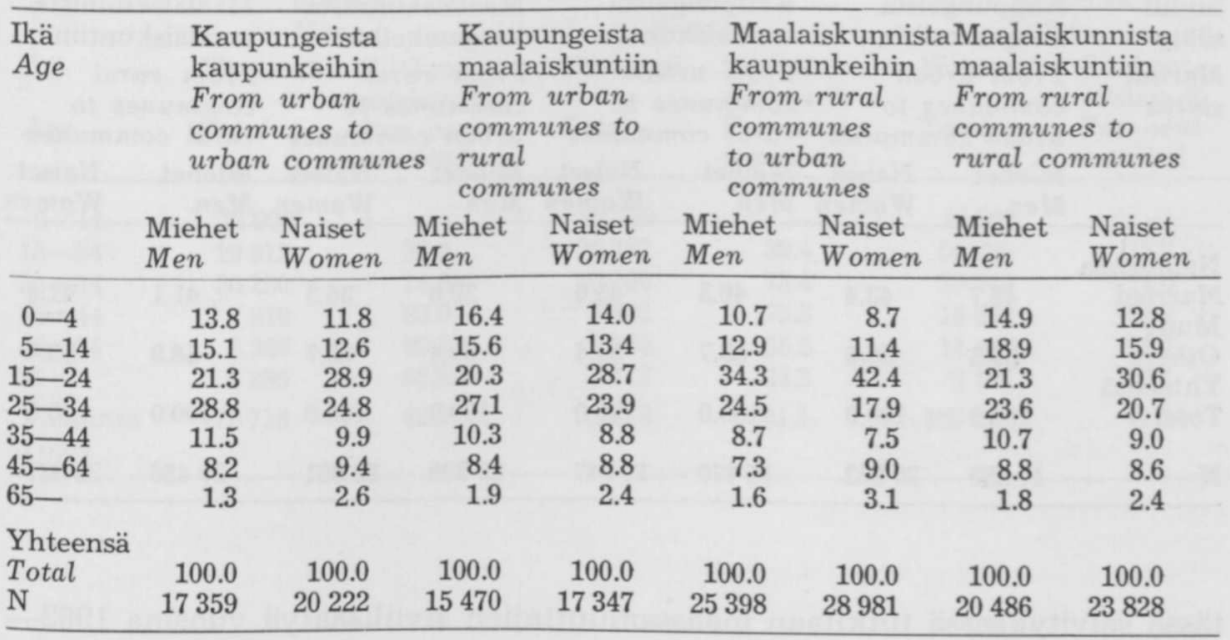

T a u l u k k o 6 . Maassamuuttajien siviilisääty muuton suunnan mukaan vuosina $1962-65 \%$ :na

Table 6. Marital status of migrants between 1962-1965, according to direction of migration (in per cent)

\begin{tabular}{|c|c|c|c|c|}
\hline $\begin{array}{l}\text { Siviili- } \\
\text { sääty } \\
\text { Marital } \\
\text { status }\end{array}$ & $\begin{array}{l}\text { Kaupungeista } \\
\text { kaupunkeihin } \\
\text { From urban } \\
\text { communes } \\
\text { to urban } \\
\text { communes }\end{array}$ & $\begin{array}{l}\text { Kaupungeista } \\
\text { maalaiskuntiin } \\
\text { From urban } \\
\text { communes to } \\
\text { rural communes }\end{array}$ & $\begin{array}{l}\text { Maalaiskunnista } \\
\text { kaupunkeihin } \\
\text { From rural } \\
\text { communes to } \\
\text { urban communes }\end{array}$ & $\begin{array}{l}\text { Maalaiskunnista } \\
\text { maalaiskuntiin } \\
\text { From rural } \\
\text { communes to } \\
\text { rural communes }\end{array}$ \\
\hline $\begin{array}{l}\text { Naimisissa } \\
\text { Married } \\
\text { Muut }\end{array}$ & 44.9 & 45.9 & 37.8 & 41.4 \\
\hline $\begin{array}{l}\text { Others } \\
\text { Yhteensä }\end{array}$ & 55.1 & 54.1 & 62.2 & 38.6 \\
\hline Total & 100.0 & 100.0 & 100.0 & 100.0 \\
\hline $\mathrm{N}$ & 37581 & 32817 & 54379 & 44313 \\
\hline
\end{tabular}

\section{Siviilisääty}

Maassamuuttajien siviilisäädyn kohdalla muuttoliiketilasto on hyvin suppea. Sen perusteella on mahdollista tutkia vain kahta ryhmää, naimisissa olevia ja muita. Massamme aikaisemmin suoritetuissa tutkimuksissa on maassamuuton todettu valikoivan enemmän naimattomia henkilöitä. Kun 
Ta ulukko 7. Maassamuuttajien siviilisääty sukupuolen ja muuton suunnan mukaan \%:na

Table 7. Marital status of migrants between 1962-1965, according to sex and direction of migration (in per cent)

\begin{tabular}{|c|c|c|c|c|c|c|c|c|}
\hline \multirow{3}{*}{$\begin{array}{l}\text { Siviili- } \\
\text { sääty } \\
\text { Marital } \\
\text { status }\end{array}$} & \multirow{2}{*}{\multicolumn{2}{|c|}{$\begin{array}{l}\text { Kaupungeista } \\
\text { kaupunkeihin } \\
\text { From urban } \\
\text { communes to } \\
\text { urban communes }\end{array}$}} & \multirow{2}{*}{\multicolumn{2}{|c|}{$\begin{array}{l}\text { Kaupungeista } \\
\text { maalaiskuntiin } \\
\text { From urban } \\
\text { communes to } \\
\text { rural communes }\end{array}$}} & \multirow{2}{*}{\multicolumn{2}{|c|}{$\begin{array}{l}\text { Maalaiskunnista } \\
\text { kaupunkeihin } \\
\text { From rural } \\
\text { communes to } \\
\text { urban communes }\end{array}$}} & \multirow{2}{*}{\multicolumn{2}{|c|}{$\begin{array}{l}\text { Maalaiskunnista } \\
\text { maalaiskuntiin } \\
\text { From rural } \\
\text { communes to } \\
\text { rural communes }\end{array}$}} \\
\hline & & & & & & & & \\
\hline & $\begin{array}{l}\text { Miehet } \\
\text { Men }\end{array}$ & $\begin{array}{l}\text { Naiset } \\
\text { Women }\end{array}$ & $\begin{array}{l}\text { Miehet } \\
\text { Men }\end{array}$ & $\begin{array}{l}\text { Naiset } \\
\text { Women }\end{array}$ & $\begin{array}{l}\text { Miehet } \\
\text { Men }\end{array}$ & $\begin{array}{l}\text { Naiset } \\
\text { Women }\end{array}$ & $\begin{array}{l}\text { Miehet } \\
\text { Men }\end{array}$ & $\begin{array}{l}\text { Naiset } \\
\text { Women }\end{array}$ \\
\hline $\begin{array}{l}\text { Naimisissa } \\
\text { Married } \\
\text { Muut }\end{array}$ & 46.7 & 43.4 & 46.3 & 45.6 & 39.6 & 36.3 & 41.1 & 41.6 \\
\hline $\begin{array}{l}\text { Others } \\
\text { Yhteensä }\end{array}$ & 53.3 & 56.6 & 53.7 & 54.4 & 60.4 & 63.7 & 58.9 & 58.4 \\
\hline & 100.0 & 100.0 & 100.0 & 100.0 & 100.0 & 100.0 & 100.0 & 100.0 \\
\hline $\mathrm{N}$ & 17359 & 20222 & 15470 & 17347 & 25398 & 28981 & 20486 & 23827 \\
\hline
\end{tabular}

tässä selvityksessä tutkitaan maassamuuttajien siviilisäätyä vuosina 1962 65 on naimattomia, leskiä ja eronneita käsiteltävä yhtenä ryhmänä ja verrattava sitä naimisissa oleviin.

Naimisissa olevien osuus maassamuuttajista oli $41.9 \%$. Naisista oli naimisissa $41.1 \%$ ja miehistä $42.9 \%$. Naimisissa olevien osuus ei muuttajien keskuudessa ole vähäisempää kuin maan koko väestössä, sillä koko maassa oli naimisissa olevien osuus samana ajanjaksona $41.6 \%$.

Muuton suunnan vaikutus naimisissa olevien osuuteen käy ilmi taulukosta 6.

Nuorten suuresta osuudesta maalaiskunnista kaupunkeihin ja kauppaloihin suuntautuvassa muuttoliikkeessä johtuu, että naimisissa olevien osuus on tähän suuntaan muuttavien keskuudessa vähäisin. Kaupungeista muuttajat ovat useimmin naimisissa olevia.

Sukupuolten väliset eroavuudet ovat melko pienet (taulukko 7).

Naimisissa olevat miehet muuttavat jonkin verran enemmän kuin naimisissa olevat naiset silloin kun muutot suuntautuvat maalaiskunnista kaupunkeihin ja kauppaloihin tai tapahtuvat kaupunkien ja kauppaloiden välillä.

Ikä ja siviilisääty liittyvät läheisesti yhteen. Siksi onkin syytä tarkastella ikäluokittain naimisissa olevien osuutta.

Naimisissa olevien osuus on suurin 35-44-vuotiaiden ikäluokassa ja vähäisin 15-24-vuotiailla. Naimisissa olevien miesten osuus on huomattava 25 vuodesta ylöspäin. Naisten osuus sen sijaan vähenee huomattavasti vanhimmissa ikäluokissa. 65-vuotiaista tai sitä vanhemmista naismuuttajista on naimisissa enää vain $24 \%$ (taulukko 8). 
Ta ulukko 8. Maassamuuttajat siviilisäädyn ja iän mukaan vuosina 1962-65 \%:na

Table 8. The distribution of migrants between 1962-1965, according to marital status and age (in per cent)

\begin{tabular}{|c|c|c|c|c|c|c|}
\hline \multirow[b]{2}{*}{$\begin{array}{l}\text { Ikä } \\
\text { Age }\end{array}$} & \multicolumn{2}{|c|}{$\begin{array}{l}\text { Miehet } \\
\text { Men }\end{array}$} & \multicolumn{2}{|c|}{$\begin{array}{l}\text { Naiset } \\
\text { Women }\end{array}$} & \multicolumn{2}{|c|}{$\begin{array}{l}\text { Yhteensä } \\
\text { Total }\end{array}$} \\
\hline & $\begin{array}{l}\text { Yhteensä } \\
\text { Total }\end{array}$ & $\begin{array}{l}\text { Siitä nai- } \\
\text { misissa \% } \\
\text { Per cent } \\
\text { married }\end{array}$ & $\begin{array}{l}\text { Yhteensä } \\
\text { Total }\end{array}$ & $\begin{array}{l}\text { Siitä nai- } \\
\text { misissa \% } \\
\text { Per cent } \\
\text { married }\end{array}$ & $\begin{array}{l}\text { Yhteensä } \\
\text { Total }\end{array}$ & $\begin{array}{l}\text { Siitä nai- } \\
\text { misissa \% } \\
\text { Per cent } \\
\text { married }\end{array}$ \\
\hline $0-14$ & 22909 & - & 22359 & - & 45268 & - \\
\hline $15-24$ & 19912 & 30.2 & 30387 & 39.4 & 50299 & 35.7 \\
\hline $25-34$ & 20250 & 74.6 & 19290 & 73.4 & 39540 & 74.0 \\
\hline $35-44$ & 7979 & 83.0 & 7861 & 75.3 & 15840 & 79.2 \\
\hline $45-64$ & 6368 & 80.8 & 8069 & 55.5 & 14437 & 66.7 \\
\hline $65-$ & 1295 & 66.8 & 2412 & 24.3 & 3707 & 39.1 \\
\hline $\begin{array}{l}\text { Yhteensä } \\
\text { Total }\end{array}$ & 78713 & 42.9 & 90378 & 41.1 & 169091 & 41.9 \\
\hline
\end{tabular}

Elinkeinorakenne

Muuttoliikkeen ammatinmukaisen valikoivuuden on todettu vaihtelevan eri ajankohtina ja eri yhteiskuntatyypeissä. Muuttajien ja koko väestön elinkeinorakennetta vertaamalla saadaan jonkinlainen käsitys muuttoliikkeen elinkeinon mukaisesta valikoivuudesta. Mitä suurempia näiden väliset erot ovat sitä enemmän muuttoliike on elinkeinohaaran mukaan valikoivaa. On kuitenkin otettava huomioon, että koko väestön ja muuttajien elinkeinorakennetta olisi verrattava samana ajankohtana, koska elinkeinorakenne on ajankohdasta riippuvainen ja vaihtelee kulloinkin vallitsevien olosuhteiden mukaan. Tässä selvityksessä on jouduttu suorittamaan vuosina 1962-65 muuttaneiden elinkeinorakenteen vertailu koko maan väestön elinkeinorakenteeseen vuonna 1960 , mikä on otettava huomioon tuloksia tarkasteltaessa (taulukko 9).

Teollisuuden piirissä työskentelevät muodostavat maassamuuttajista melkein kolmasosan, palveluksissa toimivien osuuden ollessa viidesosa. Maa- ja metsätaloudessa sekä kaupan alalla työskenteleviä on muuttajien keskuudessa yhtä paljon. Kun tätä jakautumaa verrataan maan koko väestön elinkeinojakautumaan vuonna 1960 , todetaan teollisuuden parissa työskentelevien muuttajien olevan edustettuna samassa suhteessa kuin teollisuudessa työskenteleviä oli koko väestössä. Maa- ja metsätaloudessa 
T a u l u k k o 9. Maassamuuttajat vuosina $1962-65$ ja koko väestö 31.12. 60 elinkeinon mukaan

Table 9. Migrants between 1962-65 and total population 31. 12. 60 , according to industry

\begin{tabular}{|c|c|c|c|c|}
\hline & $\begin{array}{l}\text { Maassamuuttaja } \\
\text { Migrants 1962- }\end{array}$ & $\begin{array}{l}\mathrm{t} 1962-65 \\
1965\end{array}$ & $\begin{array}{l}\text { Koko väestö } \\
\text { Total popula } \\
\text { 31.12. } 60\end{array}$ & $\begin{array}{l}31.12 .60 \\
\text { tion }\end{array}$ \\
\hline $\begin{array}{l}\text { Maa- ja metsätalous } \\
\text { Aqriculture and forestry }\end{array}$ & 12.3 & & 31.7 & \\
\hline $\begin{array}{l}\text { Agrculture ana jorestry } \\
\text { Teollisuus }\end{array}$ & 31.4 & & 30.8 & \\
\hline Industry & & & & \\
\hline $\begin{array}{l}\text { Kauppa } \\
\text { Commerce }\end{array}$ & 12.0 & 48.3 & 8.8 & 46.4 \\
\hline Liikenne & 4.9 & & 6.71 & \\
\hline $\begin{array}{l}\text { Communications } \\
\text { Palvelukset yht.kunnalle ja } \\
\text { elinkeinoelämälle }\end{array}$ & 140 & & & \\
\hline $\begin{array}{l}\text { Community and business services } \\
\text { Henkilökohtaiset palvelukset } \\
\text { Personal services }\end{array}$ & & 19.3 & & 10.8 \\
\hline $\begin{array}{l}\text { Elinkeinohaara tuntematon ja } \\
\text { ammatittomat } \\
\text { Industry unknown and economically } \\
\text { inactive persons }\end{array}$ & 20.1 & & $\begin{array}{r}\left.10.9^{1}\right) \\
\left.0.3^{2}\right)\end{array}$ & \\
\hline Yhteensä - Total & $\begin{array}{r}100.0 \\
168560\end{array}$ & & $\begin{array}{r}100.0 \\
4446222\end{array}$ & \\
\hline
\end{tabular}

1) itsenäiset ammatittomat economically inactive persons

2) tuntematon unknown

työskentelevät sen sijaan eivät muuta läheskään siinä määrin kuin heidän osuutensa koko väestöstä edellyttäisi. Palvelusten ja kaupan parissa työskentelevien osuus on muuttajien keskuudessa suurempi kuin koko väestössä.

Muuton suunta todennäköisesti vaikuttaa siihen kuinka paljon kunkin elinkeinohaaran alalta muuttaa (taulukko 10). Maa- ja metsätalouden piirissä työskentelevät muuttavat eniten maalaiskunnasta toiseen, myös kaupunkiin muuttaneiden joukossa heitä on jonkin verran. Kaupunkien ja kauppaloiden välisissä muutoissa heidän osuutensa luonnollisesti on pieni.

Maalaiskuntien välisiä muuttoja lukuunottamatta on teollisuuden piirissä työskenteleviä muuttajia ylivoimaisesti eniten. Kaupunkien ja kauppaloiden välisissä muutoissa on kaupan ja palvelusten piirissä työskentelevien muuttajien osuus suurempi kuin muihin suuntiin tapahtuvissa muutoissa. Myöskin sellaisia, joiden ammattia ei tunneta tai jotka ovat ilman ammattia, on heidän keskuudessaan eniten. 
Taulukko 10. Maassamuuttajat elinkeinohaaran ja muton suunnan mukaan vuosina $1962-65 \%$ :na

Table 10. The distribution of migrants according to employment in various industries and direction of migration (in per cent)

\begin{tabular}{|c|c|c|c|c|}
\hline $\begin{array}{l}\text { Elinkeino- } \\
\text { haara } \\
\text { Branch of } \\
\text { industry }\end{array}$ & $\begin{array}{l}\text { Kaupungeista } \\
\text { kaupunkeihin } \\
\text { From urban } \\
\text { communes } \\
\text { to urban } \\
\text { communes }\end{array}$ & $\begin{array}{l}\text { Kaupungeista } \\
\text { maalaiskuntiin } \\
\text { From urban } \\
\text { communes } \\
\text { to rural } \\
\text { communes } \\
\end{array}$ & $\begin{array}{l}\text { Maalaiskunnista } \\
\text { kaupunkeihin } \\
\text { From rural } \\
\text { communes to } \\
\text { urban } \\
\text { communes }\end{array}$ & $\begin{array}{l}\text { Maalaiskunnista } \\
\text { maalaiskuntiin } \\
\text { From rural } \\
\text { communes to } \\
\text { rural communes }\end{array}$ \\
\hline $\begin{array}{l}\text { Maa- ja } \\
\text { metsätalous } \\
\text { Agriculture and } \\
\text { forestry }\end{array}$ & 1.8 & 6.0 & 10.3 & 28.2 \\
\hline $\begin{array}{l}\text { Teollisuus } \\
\text { Industry }\end{array}$ & 31.7 & 37.2 & 34.6 & 23.2 \\
\hline $\begin{array}{l}\text { Kauppa } \\
\text { Commerce }\end{array}$ & 13.7 & 10.7 & 11.7 & 11.8 \\
\hline $\begin{array}{l}\text { Liikenne } \\
\text { Communications } \\
\text { Palvelukset } \\
\text { yht.kunnalle ja }\end{array}$ & 4.9 & 5.5 & 5.2 & 4.1 \\
\hline $\begin{array}{l}\text { elinkeinoelämälle } \\
\text { Community and } \\
\text { business services } \\
\text { Henkilökohtaiset }\end{array}$ & 18.7 & 13.6 & 11.6 & 13.3 \\
\hline $\begin{array}{l}\text { Henkilökohtaiset } \\
\text { palvelukset } \\
\text { Personal services } \\
\text { Elinkeinohaara } \\
\text { tuntematon ja }\end{array}$ & 4.8 & 4.4 & 7.4 & 3.9 \\
\hline $\begin{array}{l}\text { ammatittomat } \\
\text { Industry unknown } \\
\text { and economically } \\
\text { inactive persons }\end{array}$ & 24.4 & 22.6 & 19.2 & 15.5 \\
\hline Yhteensä - Total & 100.0 & 100.0 & 100.0 & 100.0 \\
\hline $\mathrm{N}$ & 37468 & 32429 & 54378 & 44285 \\
\hline
\end{tabular}

Koska ammatinmukaisen valinnan on todettu olevan suuresti ajankohdasta riippuvainen, on kuviossa 2 esitetty muuton suunnan mukaan muuttajien elinkeinohaaran mukainen jakaantuminen vuosittain vuodesta 1956 alkaen. Tämä kymmenen vuoden pituinen kausi osoittaa kuinka suuria vuosittaiset vaihtelut ovat.

Kuvion 2 mukaan vuosittaiset heilahtelut saattavat olla hyvinkin suuria, joskus jopa $10 \%$. Varsinkin teollisuuden sekä maa- ja metsätalouden piirissä tämä on havaittavissa. Maa- ja metsätaloudessa työskenteleviä lukuunottamatta on muilla elinkeinoaloilla työskentelevien osuus parina viime vuotena lisääntynyt kaikkiin suuntiin tapahtuvissa muutoissa. 
Kaupungeista ja kauppaloista kaupunkeihin ja kauppaloihin From urban communes to urban communes

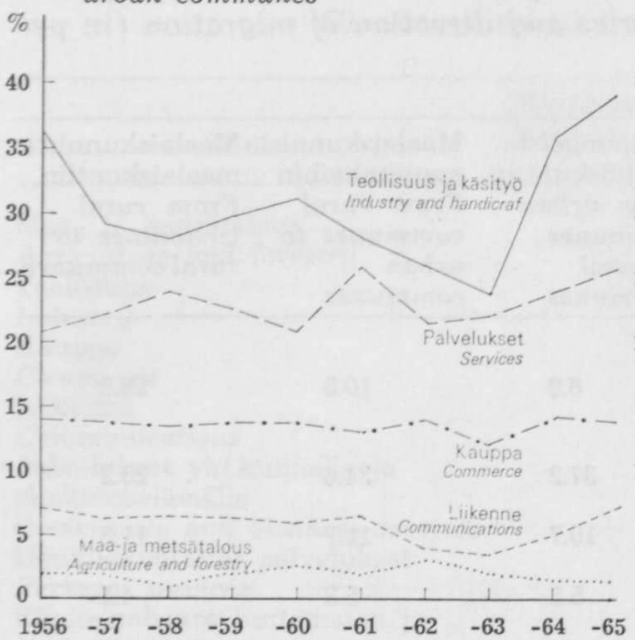

Maalaiskunnista kaupunkeihin ja kauppaloihin

From rural communes to urban communes

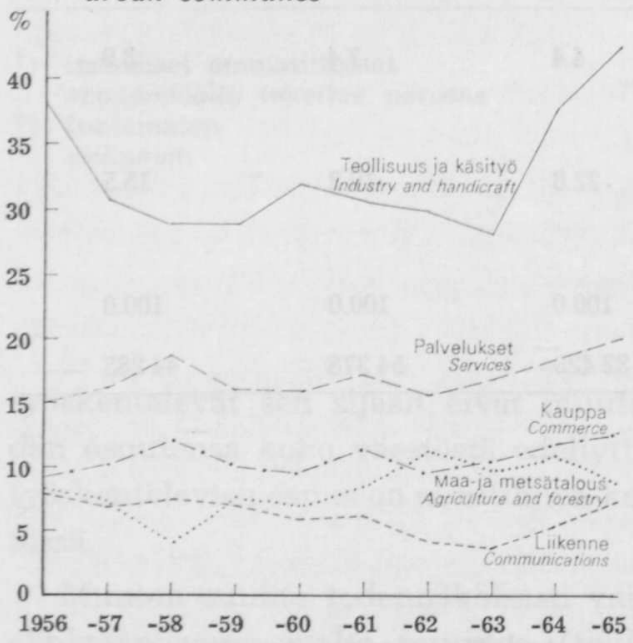

Kaupungeista ja kauppaloista maalaiskuntiin

From urban communes to rural communes

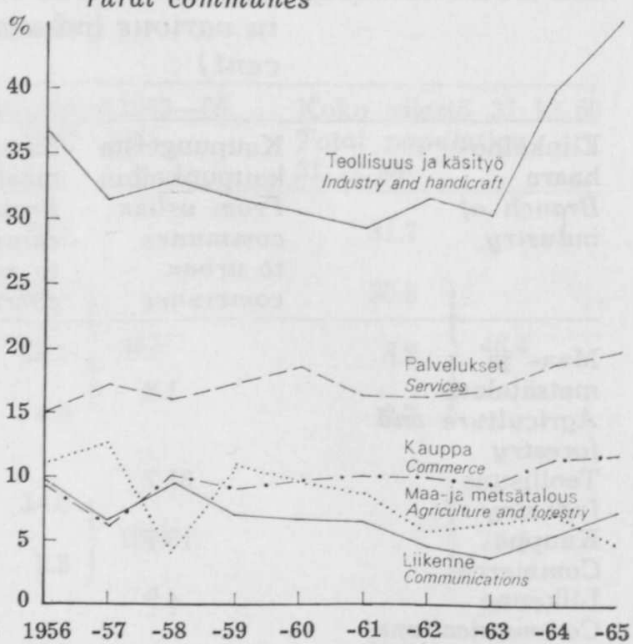

Maalaiskunnista maalaiskuntiin From rural communes to rural communes

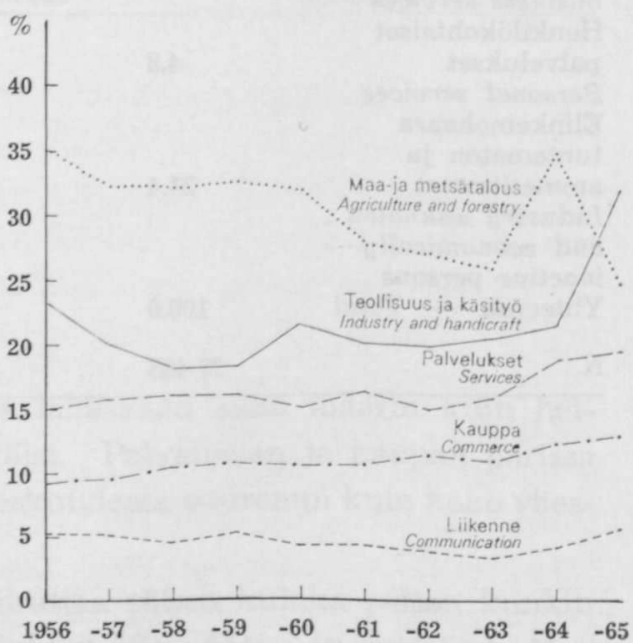

Kuvio 2. Maassamuutto muuton suunnan sekä muuttaneiden elinkeinohaaran mukaan vuosina $1956-65 \%$ :na

Figure 2. Migration between 1956-65, by direction of migration and by industry of migrants (in per cent)

Sosia aliryhmä

Vuodesta 1961 lähtien on muuttoliiketilastoomme otettu mukaan myös muuttajien sosiaaliryhmä. Ammatin tai oppiarvon perusteella maassa- 
T a u lukko 11. Itsenäisesti muuttaneet sosiaaliryhmän ja muuttajien sukupuolen mukaan vuosina $1961-65 \%$ :na

Table 11. Distribution of migrants of age between 1961-1965, according to social class and sex (in per cent)

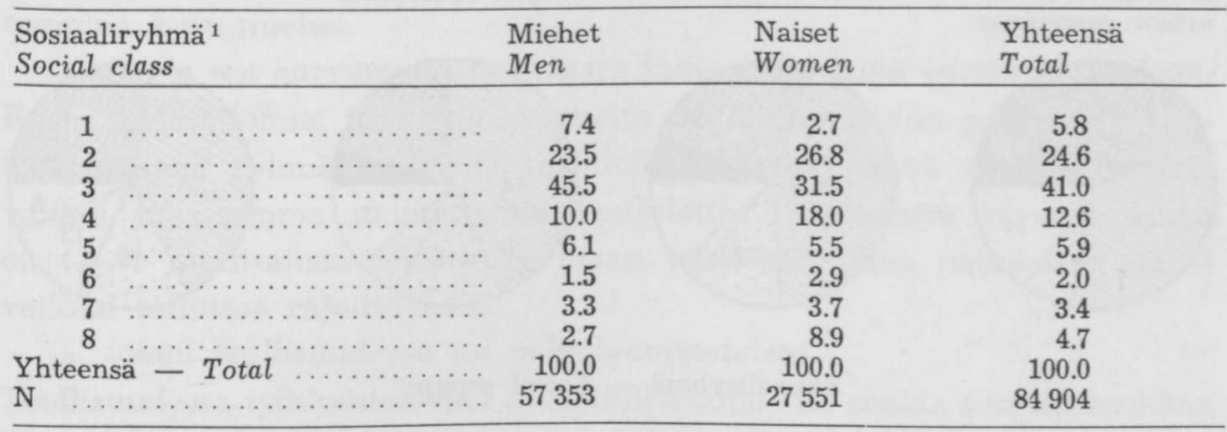

1) 1. Akateemisen loppututkinnon suorittaneet henkilöt, suuryrittäjät ja yritysten johtajat, julkisen ja yksityisen sektorin johtavat toimihenkilöt.

Professionals, employers of larger establishments and managers, higher employees in public and private employment.

2. Julkisen ja yksityisen sektorin alemmat toimihenkilöt, itsenäiset pienyrittäjät, teknikot, työnjohtajat sekä muut henkilöt, joiden ammattia ei voida rinnastaa sosiaaliryhmiin 1 ja 3 kuuluviin ammatteihin.

Lower employees in public and private employment, independent employers of smaller establishments, technicians, foremen and other persons whose occupations cannot be ranked in the same category as those in the social groups 1 and 3 .

3. Erikoiskoulutuksen saaneet työntekijät, kauppa-apulaiset ja näihin ammatteihin verrattavat.

Skilled workers, shop assistants and related occupations.

4. Työntekijät, joilla on vähän tai ei ollenkaan erikoiskoulutusta.

Labourers possessing little or no special training.

5. Itsenäiset maanviljelijät yms.

Independent farmers and other related occupations.

6. Oppilaat ja harjoittelijat.

Pupils and apprentices.

7. Opiskelijat ja koululaiset.

Students and pupils at school.

8. Epämääräinen tai tuntematon ammatti.

Unknown or uncertain occupation.

muuttajat on jaettu kahdeksaan sosiaaliryhmään. Koko väestön osalta ei ole mahdollisuutta saada vastaavaa jakautumaa. Siksi vertailu ei ole mahdollista.

Vuosina 1961-65 itsenäisesti muuttaneet jakaantuivat sosiaaliryhmän mukaan taulukon 11 mukaisesti.

Kolmas sosiaaliryhmä eli erikoiskoulutuksen saaneet työntekijät muuttaa eniten maassamme. Toinen ja neljäs sosiaaliryhmä ovat seuraavaksi suurimmat. Itsenäisiä maanviljelijöitä on muuttajista vain kuusi prosenttia samoinkuin ensimmäiseen sosiaaliryhmään kuuluviakin.

Miesten ja naisten välillä on huomattavia eroavuuksia. Miehistä melkein puolet kuuluu kolmanteen sosiaaliryhmään, naisista vain kolmannes. 
Kaupungeista ja kauppaloista kaupunkeihin ja kauppaloihin From urban communes to urban communes
Kaupungeista ja kauppaloista maalaiskuntiin From urban communes to rural communes

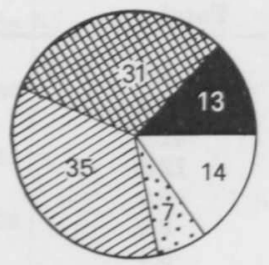

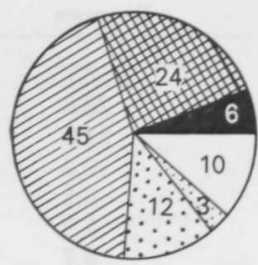

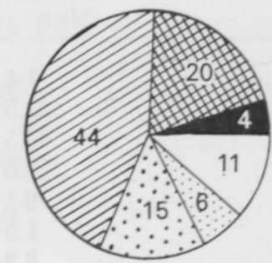

Maalaiskunnista maalaiskuntiin From rural communes to rural communes communes to urban communes

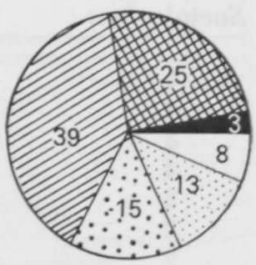

Sosiaaliryhmä - Social groups

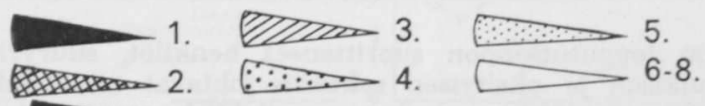

K u vi o 3. Itsenäisesti muuttaneet muuton suunnan ja sosiaaliryhmän mukaan vuosina $1961-65 \%$ :na.

Figure 3. Distribution of migrants of age between 1961-1965, according to direction of migration and social class (in per cent).

Naiset sen sijaan muuttavat enemmän erikoiskoulutusta vailla olevinakin. Kahdeksannen sosiaaliryhmän suuruus naisten keskuudessa johtuu siitä, että tähän on luokiteltu sellaiset naiset, jotka ovat maininneet ammatikseen rouva. Ylin sosiaaliryhmä on miesmuuttajilla suurempi kuin naisilla.

Sosiaaliryhmiin kuulumiseen vaikuttaa muuton suunta kuten todetaan kuviosta 3.

Kolmas sosiaaliryhmä on suurin tapahtuupa muutto mihin suuntaan tahansa. Eniten tähän ryhmään kuuluvia on kuitenkin kaupunkien ja maalaiskuntien välisissä muutoissa. Kahteen ylimpään sosiaaliryhmään kuuluvia on eniten kaupungeista ja kauppaloista kaupunkeihin ja kauppaloihin muuttavien joukossa. Maalaiskunnista sen sijaan muuttaa enemmän erikoiskoulutusta vailla olevia työntekijöitä. On selvää, että itsenäisten maanviljelijöiden osuus on suurin maalaiskuntien välisissä muutoissa. Viimeiseen sosiaaliryhmään kuuluvia muuttaa kaupungeista enemmän kuin maalaiskunnista.

\section{Loppupäätelmä}

Yhteenvetona 1960-luvun alkupuolen suomalaisesta maassamuuttajasta voidaan sanoa, että hän

- on useammin nainen kuin mies,

Ero ei ole suuri, mutta se on havaittavissa muuton suunnasta ja pituudesta riippumatta ja kaikissa osissa maata. 
- on tavallisesti nuori henkilö,

15-24-vuotiaiden osuus on suurin ja alle 35-vuotiaita on muuttajista peräti $80 \%$. Nuoriso on runsaimmin edustettuna maalaiskunnista kaupunkeihin ja kauppaloihin suuntautuvissa muutoissa. Naiset muuttavat nuorempina kuin miehet.

- ei ole sen harvemmin naimisissa kuin maan koko väestö yleensä on, Koska naimattomia, leskiä ja eronneita on väestötilaston perusteella tutkittu yhtenä ryhmänä, ei ole mahdollista sanoa, missä määrin muutto valikoi maassamme naimattomia henkilöitä. Naimisissa olevien osuus on $42 \%$ muuttajista sekä koko maan väestöstä, joten naimisissa olo ei vaikuta muuttoa rajoittavasti.

- toimii teollisuudessa tai palveluammateissa,

Teollisuudessa työskentelevien muuttajien osuus on samaa suuruusluokkaa kuin teollisuudessa toimivien osuus koko väestöstä. Palveluammatit ja kauppa sen sijaan vetävät muuttajia puoleensa ja niistä muutetaan. Maaja metsätaloudessa toimivien osuus on huomattavampi ainoastaan maalaiskuntien välisissä muutoissa.

- kuuluu usein kolmanteen sosiaaliryhmään, ts. erikoiskoulutuksen saaneisiin työntekijöihin.

Lähes puolet miesmuuttajista on kolmanteen sosiaaliryhmään kuuluvia, naisista kolmannes. Naiset sen sijaan muuttavat useammin erikoiskoulutusta vailla olevinakin, ts. neljännestä sosiaaliryhmästä. Kolmas sosiaaliryhmä on suurin kaikkiin suuntiin tapahtuvissa muutoissa. Kahteen ylimpään sosiaaliryhmään kuuluvia on eniten kaupunkien ja kauppaloiden välisissä muutoissa.

\section{Kirjallisuus}

Allardt, E.-Jartti, P.-Jyrkilä, F.-Littunen, Y. Nuorison harrastukset ja yhteisön rakenne. Porvoo 1958.

Bogue, D. J. Internal Migration. Teoksessa Hauser-Duncan, The Study of Population. Chigago 1959.

Bruun, K. Tutkimus kaupunkiin muuttaneista 1953. Tilastollisia kuukausitietoja Heìsingistä 1955, 3.

Fougstedt, G. Maassamuutto Suomessa ja sitä käsittelevä tilasto. Kansantaloudellinen Aikakauskirja 1953, 3.

Illsley, R.-Finlayson, A.-Thompson, B. The Motivation and Characteristics of Internal Migrants. The Milbank Memorial Fund Quarterley 1963, 2 ja 3.

Lee, E. S. A theory of migration. Demography 1966, Vol. 3. Number 1.

Lento, R. Muuttoliikkeestä ja sen syistä eräissä Kuopion läänin kunnissa vuosina 1921-1944. Väestöliiton vuosikirja II. Helsinki 1948.

Lento, $R$. Maassamuutto ja siihen vaikuttaneet tekijät Suomessa vuosina 18781939. Helsinki 1951.

Petersen, W. Population. New York 1961. 
Piepponen, P.-Ritamies, M. Miesten ylikuolevuus Suomessa. Väestöpoliittisen Tutkimuslaitoksen julkaisuja sarja B N:o 3, 1966.

Rosenberg, A. Muuttoliike Uudenmaan läänissä esi-industrialistisen kauden lopulla (1821-1880). Helsinki 1906.

Sjöberg, A. Perttelin muuttovoitto ja maaltapako vuosina 1921-1945. Moniste. Helsinki 1947.

Suomen Tilastollinen Vuosikirja 1961-1966. Helsinki 1962-67.

Valkonen, T.-Kukkonen, K. Maaltamuuton valikoivuudesta. Väestöntutkimuksen Vuosikirja IX, 1965-66. Vammala 1966.

Wallander, J. Flykten från skogsbygden. Stockholm 1948.

Varpela, E. Kokonaiskuolleisuudesta kaupunkiin suuntautuvan muuttoliikkeen yhteydessä. Sosiaalilääketieteellinen Aikakauslehti 1964, 5.

Väestönmuutokset 1960-1954. SVT VI A: 119, 120, 122-124. Helsinki 1962-1966.

\section{Summary:}

\section{Demographic Characteristics of the Migrants in the 1960's}

\section{By MARKETTA RITAMIES}

Population Research Institute

Although internal migration in Finland has been on the continuous increase at present the annual number of migrants already being over 200,000 - little attention has been paid to their demographic characteristics. Research along these lines, however, would indicate what are the associated characteristics and to what extent migration is selective. As such it would help us understand the observable differences between the composition of the population in general and the variations in the prevailing conditions in the migrants' communities of origin and destination.

The purpose of the present report is to show what demographic characteristics of the migrants can be studied by means of available census data for the beginning of the 1960's, and to indicate to what extent migration is selective in respect to the variables studied.

On the basis of census data, which is to a large extent based on population samples, the following variables can be studied: sex, age, marital status, occupational status and social class. In brief, the migrants of the early part of the 1960's can be characterized as:

- The migrant is more often a woman than a man.

The difference is not large (the proportion of women is 53 per cent), but it is notably independent of either the direction or the distance of migration, and holds for the whole country (Tables 1 and 2).

- The migrant is usually a young person.

The proportion of persons between the ages of 15 and 24 years is the highest, and 80 per cent of the migrants are under 35 years of age. The corresponding proportion for the total population is 58 per cent. Young persons are most represented among migrants moving from rural to urban communes. Migrants moving from urban communes are somewhat older because the migration patterns of cities are of a more transitory nature. People moving away from the cities are often those who have earlier, as young persons, migrated there (Tables 3,4 , and 5 ).

- Migrants are no less seldom married than the population in general. 
Because in census statistics single persons, widows, and divorced are counted together, it is impossible to say to what extent migration is selective with respect to single persons. The proportion of married persons among migrants is 42 per cent, which is the same as for the total population. Thus, being married has no effect on migration. The proportion of married persons is lowest among migrants moving from rural to urban communes. This may be due to the fact that people move from rural communes at a younger age than they do from the cities (Tables 6, 7, and 8).

- Migrants are employed in industry and service occupations.

One half of the migrants are employed in industry and service occupations. Only little migration is noted among persons engaged in agriculture and forestry. Only in case of migrations from one rural commune to another was their proportion somewhat more noticeable i.e. 28 per cent. Services and commerce are the industries that both attract migrants and from which they move. The migrants' occupation is dependent on both the time of migration and the prevailing conditions. Annual variations in the distribution of migrants in the various industries were large. For example, the proportion engaged in industry varied depending on the direction of migration as much as 10 per cent (Figure 2).

- Migrants belong often to social class 3 , i.e. skilled workers.

According to census classification migrants fall into 8 social classes (cf. p. 123). 41 per cent of the migrants were found in social class 3. Also in social class 2 there is much migration ( 25 per cent). On the other hand, the proportion in the lowest and highest social classes is small. Only 6 per cent of the migrants come from each of these classes.

Almost one half of the male migrants but only about a third of the female come from social class 3 . Thus, even though they have less specialized training, women migrate more. There are also more women in social class 8 , which includes unskilled workers and those with unknown occupation.

Migration in all directions is highest in social class 3. Among migrants from the two uppermost social classes migration is mostly between urban communes. (Table 11). 